\title{
ON SOME NEW GENERA AND SPECIES OF COLEOPTERA IN THE TRING MUSEUM.
}

BY DR. K. JORDAN.

\section{Hexarthrius aduncus sp. nov.}

(Pl. XIII., fig. 1.)

§. H. niger, infra parum rubescens, elytris obscure rubro-castaneis, abdomine et pedibus anticis obscure rubris, pedibus quatuor posticis (tarsis subnigris exceptis) rubris.

Mandibulae modice inclinatae, quatuor dentibus armatae, dente primo basali truncato versus posticum directo (fere sicut in Cladognatho giraffa), tertio magno subacnto recto conico in tertia parte apicali ; secundo parvo inter primum et tertium, primo plus quam tertio approximato, quarto parvo ante apicem sito, apice ipso simplice, inter apicem et dentem tertiam paucis denticulis instructae, margine exteriore e regione dentis tertii parum incurvato ; basi sine carina aut dente dorsali. Clypeus parvus, triangularis, valde inclinatus, simplex ; caput medio minime impressum, sat planatum, margine anteriore medio vix producto, utrimque leviter sinuato, angulis anticis interioribus rotundatis, paulo magis quam marginis medium versus anticum prominentibus, exterioribus (ante oculos) rectis. Prothorax medio levissime canaliculatus, lateribus fortiter (sicut caput), disco minutius granulosus, in apice parum augustior quam ante basim. Elytra laevia, sine sculptura distincta.

Mentum et caput infra fortiter, prosternum minutius, metasternum minutissime granulosa ; abdomen laeve.

Long. (mand. excl.) $50 \mathrm{~mm}$., mandibl. 24, elytr. 27, lat. 20.

Allied to $H$. davisoni Waterh., which has also an interior basal tooth on the mandibles directed backwards; but this tooth is acuminate in $H$. davisoni, while it is truncate in the new form; then there is a smaller tooth at the end of the basal third of the mandible, which is wanting in $H$. davisoni, and the largest tooth is much farther from the tip of the mandible than in Ch. O. Waterhouse's species, since it stands just before the beginning of the apical third; the outer edge of the mandible opposite the large tooth is somewhat bent inwards.

Hab. Assam. Three males of the same size.

\section{Hexarthrius elongatus sp. nov.}

$\delta$ (forma minor). $H$. niger, parum brunnescens, elytris postice plaga sat parva indistincte circumseripta pallide castanea notatis, pedibus (genibus tarsique exceptis) castaneis.

Mandibulae versus medinm levissime latiores, ab medio inclinatae, in basi vix, dein gradatim leviter arcuatae, in tertia parte apicali dente sat brevi, ante apicem dente secundo, primo fere aequali, armatae, basi excepta obtuse denticulatae, basi in latere externo et infra subplana, carina infero-laterali medium mandibulae non attingente instructa. Clypeus tridentatus, dentibus lateralibus brevibus parum versus superum recurvatis subrectangularibus, dente mediano truncato, simplice, supra minutissime carinato. Caput dense granulatum, sicut clypeus et mandibulae, 
supra lateraliter levissime gibbosum, antice medio late depressum, angulis anticis rotundatis. Prothorax disco ante basim paucis punctis grossis notatus, sat subtiliter granulatus, lateribus sat fortiter rugato-granulatus; lateribus pone angnlos anticos prominentes dentatos sinuatis, ante basim dente sat acnto armatis. Elytra elongata, subtiliter densissime punctulata, humeris breviter dentatis.

Mentum fortiter rugatum; gula rugato-granulata, punctis magnis instructa. Prosternum transverse bisuleatum, sulcis plicatura sat elevata separatis, medio vix punctatum. Metasternum et abdomen medio vix punctulata, illnd lateribus grossissime subdense, hoc sparsim subtilius punctatum, segmento ultimo ad marginem apicalem densius sat fortiter punctato.

Long. (mand. exc.) $40 \mathrm{~mm}$., mandibl. 1\%, elytr. 25, lat. 16.

The mandibles are shaped as in small males of $H$. parryi Hope, and $H$. rhinoceros (Oliv.), with the flattened outer and underside of the base forming a kind of infero-lateral carina as in the latter species; the clypens is formed as in H. parryi, but the median tooth is truncate; the ante-ocular tooth of the head is not so high as in $H$. parryi, and hardly rectangular, though the ante-ocular earina itself is sinuate behind the tooth. The sides of the prothorax are produced towards the eyes, much more so than even in $H$. deyrollei Parry, there being a conspicuous sinus between this produced angle and the neck. The elytra are much longer than in H. parryi, and posteriorly much less rounded, much less so than in H. rhinoceros and deyrollei. The bisulcate prosternum, with an obvions fold separating the grooves, is also a character by which the new form may be distinguished from either of the three mentioned species.

From $H$. mandibularis Deyr., which I have not yet seen, it differs in colour, in the form of the elytra, in the more prominent intero-anterior angle of the head, the more blunt ante-ocular tooth, and the different outline of the prothorax.

Hab. Kina Balu (Brit. N. Borneo).

\section{3. (?) Dorcus barbarus sp. nov.}

(Pl. XIII., fig. 2.)

8. D. rubro-castaneus, mandibulis apice tarsisque subnigris. Mandibulae latitudine capitis longiores, in medio abrupte falcato-arcuatae, parte basali deplanata, dilatata, in basi dente minuto, in medio dente triangulari armata, parte apicali parum torquata, sat tenui, simplice. Clypeus fortiter transversus, leviter depressus, quadrangularis, angulis acutis minime productis, impunctatus ; caput juxta clypeum sinuatum, angulis anticis rotundatis, sed antrorsum productis, earina anteoculari parum elevata non angulata, dispersissime minute punctatum, punctis versus latera parum fortibus, pone oculos grossis panlo densioribus. Antennarum flabellum triarticulatum, articulus ante flabellum acuminatus. Prothorax longitudine plus duplo latior, apice utrinque sat fortiter sinuatus, angulis anticis valde productis, sed rotundatis, lateribus pone angulum anticum levissime rotundatis, dein usque ad angulum basalem rotundatum subrectis, basi medio utrinque leviter sinuata ; disco fortius quam caput punctatus, punctis versus latera evanescentibus, in parte laterali ipso parum deplanata distinctis, sat magnis, sed leviter impressis, pone marginem anticum grossis in una serie irregulari dispositis. Scutellnm longitudine parum latius, rotundato-triangulare, basi grosse punctatum, apice laeve. Elytra prothorace septima parte angustiora, basi truncata, humeris leviter callosa, angulo humerali breviter dentata, lateribus juxta humeros levissime 
rotundata, dein minime angustata, a tertia parte apicali rotundato-angustata, singulo elytro ad suturam subacuminato; striato-punctata, striis antice posticeque valde abbreviata, $2^{\mathrm{a}}$ et $3^{\mathrm{a}}, 4^{\mathrm{a}}$ et $5^{\mathrm{a}}, 6^{\mathrm{a}}$ et $7,8^{\mathrm{a}}$ et $9^{\mathrm{a}}$ approximatis, limbo laterali et basali dense grosse punctata, disco et parte apicali longitrorsum punctulata, praecipue versus apicem parum rugulosa.

Mentum et caput infra punctis magnis instructa. Prosternum vix punctatum, processu intercoxali elevato, pone coxas parum decrescente, in apice ipso perpendiculari. Metasternum lateraliter punctis grossis, medio sicut abdomen fere laeve ; abdominis segmenta, praecipue ultimum, lateribus punctata.

Tibiae longitrorsum multisulcatae, quatuor posticis edentatis.

Long. (mand. excl.) $19 \mathrm{~mm}$., elytr. 11, lat. (in proth.) 8.

The basal half of the mandibles stands at right angles to the apical half, but the angle itself is rounded.

I believe this form is the type of a new genus; but since I have only one specimen of the male sex before me, I place the species provisionally into Dorcus.

$H a b$. Assam.

\title{
4. Gnorimus viridis sp. nov.
}

\author{
(Pl. XIII., fig. 3.)
}

3․ G. supra obscure viridis, infra aeruginosus et pallide luteo-pilosus, nitens. Caput grossissime punctatum, punetis passim confluis, clypeo antice profunde sinuato, retrorsum pauce angustato, reflexo-marginato. Palpi antennaeque rufopiceae. Prothorax longitudine paulo latior, apice basi parum angustiore, lateribus aequabiliter leviter rotundatis, basi ad angulos parum depressa, angulis posticis rotundatis, limbo laterali pilis pallide luteis dense vestito; grosse punctatus, punctis irregulariter dispositis, passim confertius sitis, antice versus latera densis et confluis; linea mediana minime elevata pro parte laevi. Scutellum latius quam longum, apice rotundatum, hand semicirculare; basi utrimque vel tota basi punctis magnis instructa, apice laevi, linea media parum convexa. Elytra latitudine minime longiora, retrorsum pance sed distincte dilatata, apice extus fortissime rotundata, angulo suturali paulo rotundato; in singulo elytro sexstriata, interstitiis convexis, vix punctatis; limbo declivi laterali et apicali dense transverse rugulosostriolato.

Infra lateraliter dense ruguloso-striolatus ; processus mesosternalis intercoxalis compressus, prominens, antice subperpendicularis, apice rotundatus ; metasternum (ठ) medio late longitudinaliter impressum, hac impressione dense grosse punctata, ejus margine laevi, ( $q$ ) longitudinaliter canaliculatum, disperse grosse punctatum; abdomen (ठ) medio longitudinaliter impressum, impressione sat dense grosse punctata, margine ejus laevi, ( + ) convexum, medio vix deplanatum, sat disperse punctatum, segmento quinto in utroque sexu glabro, (ठ) medio sat dense punctato, apice rotundato, $(q)$ medio sparsim punctato, apice minute emarginato. Pygidium transverse ruguloso-striolatum, sparsim punctatum, (ठ) apice convexum, ( $\uparrow$ ) apice leviter impressum, hac impressione granulata; quatuor maculis luteo-pilosis notatum, tria mediana transverse disposita, una apicali. Femora pilosa sicut corpus inferum, antica infra dense, supra grossius sparsius punctata, intermedia infra ruguloso-striolata, supra rugato-punctata, postica grosse sat disperse punctata; tibiae anticae apice extus in utroque sexu dente lato sed sat longo obtuso parum arcuato armatae, $(\delta)$ post medinm extus parum dilatatae, obtuse angulatae, $(\ngtr)$ in 
tertia parte apicali dentatae; omnes tibiae, praesertim quatuor anticae extus longitudinaliter ruguloso-striatae.

Long. (eap. exel.) 19 mm., elytr. 11, lat. 10.

This form differs from the true Gnorimus in having the intercoxal process of the mesosternum produced into a narrow and anteriorly almost vertical tubercle.

Hab. Naga Hills (type) and North Manipur (Assam).

\section{Sinuaria gen. nov.}

Capite sat fortiter in prothoracem retracto; mandibulis rotundato-arenatis ; fronte medio leviter impressa; antennis articulis apice truncatis, hand serratis. Prothorace antice valde emarginato, lateribus fortissime late sinuato, inter sinum et angulum anticum oblique truncato, angulis posticis valde versus latera productis, parum arcuatis; basi medio minute bisinuata, lateraliter levissime emarginata; disco medio carinato-elevato, lateraliter depresso. Scutello subcordato, apice anguste emarginato. Elytris basi valde depressis, humeris prominulis, apice acuminatis. Prosterno antice rotundato-dilatato, sutura laterali leviter arcuata, medio elevato, utrinque inter carinam medianam et suturam impresso. Mesosterno sat declivi.

This Elaterid genus is closely allied to Oxynopterus Hope, from which it differs in the antennae not being serrate, in the peculiar shape of the prothorax, in the shoulders of the elytra much more prominent, in the more declivous mesosternum, and in the evenly rounded mandibles.

\section{Sinuaria aenescens sp. nov.}

(Pl. XIII., fig. 4.)

S. niger, parum aenescens, pube olivacea vestita. Caput rugose punctatum, impressione frontali levi pilis ochraceis sat densis tecta. Antennae capite cum prothorace vix longiores, articulo primo apice modice incrassato, tertio parum longiore, leviter arcuato. Prothorax longitudine (in medio) fere duplo (ad basim) latior, omnino minutissime densissime punctulatus, margine externo leviter crassato. Scutellum subrotundum, parum cordatum, antice latius quam postice, basi minute, apice parum profundius emarginatum, depressum, marginibus basali et apicali recurvatis. Elytra carina laterali sub angulum humeralem abbreviata, lateribus pone humeros parum impressis, omnino subtilissime creberrime transverse granulato-rugulosa, dispersis punctis, passim seriatim dispositis, praecipue prope suturam sitis instructa, indistincte longitndinaliter striata, multis impressionibus irregularibus levibus.

Infra sat dense punctulata; prosternum antice rugatum; processus prosternalis basaliter canaliculatus. Metasternum medio profunde canaliculatum. Tarsi tibiis, praecipue postici, parum longiores.

Long. 55 mm., elytr. 44, lat. 18.

Of the impressions of the elytra four are rather large (two on each elytron) and conspicuous, one situated just before the middle, the other close to the suture at the beginning of the apical third. The median carina of the prothorax and the higher parts of the elytra are rubbed, black, shining, and have an obvious tint of bronze colour.

Hab. Kiua Baln (Brit. N. Borneo). 


\section{Chrysochroa simillima sp. nov.}

ठ q. Ch. similis Saund. valde affinis, parum brevior, abdomine luteo-ochraceo. elytris lata fascia mediana in margine laterali parum angustiore lntea ornatis.

Long. $40 \mathrm{~mm}$., elytr. 30, lat. 13 .

The median band of the elytra is narrower, as it usually is in Ch. castelnaudi Deyr., and is anteriorly straight, posteriorly somewhat rounded; in some specimens of $C h$. similis Saund. which I have examined, the elytra have also a broad median band instead of two large patches, but this species is slenderer than simillima, and its abdomen golden green, while it is pale ochreous in the new form, having the sides of the first abdominal segment only golden green. The structure of the derm is alike in Ch. similis and Ch. simillima. The sides of the prothorax of the latter are bright fiery, the metasternum also fiery, and the legs blue with the femora golden green when viewed from different sides.

Hab. Barram River (N. Borneo) (A. Everett).

\section{Macrochirus vittatus sp. nov.}

8 9 . M. fulvo-lateritius. Rostrum nigrum, basis dorso excepto, carinula dorsolaterali basali instructum, inter antennas foveolatum, ( $\delta)$ omnino sat disperse punctulatum, ( $($ ) dorso antrorsum densins punctatum, linea media in apice laevi, lateribus leviter sulcatum, sulco densissime grosse punctato in quarta parte basali evanescente, apicem attingente. Caput nigrum, supra fulvo-lateritium, inter oculos foveola rotundata, in vertice paucis punctis minime impressis instructum, sublaeve. Antennae brunneo-nigrae. Prothorax longitudine latitudini aequali, nigro-quadrivittatus, duabus vittis dorsalibus intus rectis, extus parum rotundatis, antice angustioribus, marginem basalem non attingentibus, vitta in utriusque lateris medio sita angustiore basim et apicem attingente, margine apicali fusco vel nigro, basi angustissime nigro-limbata, utrimque sinuata, lobo antescutellari rotundo sed sat angusto ; fortiter punctatus, punctis in (ठ) densis grossis, passim confluis, in $(\uparrow)$ dispersioribus, sed grossis, interstitiis dense punctulatis, in ( $\delta$ ) latrorsum parum rugulosus. Scutellum minutissime granulosum, sicnt elytra. Haec margine basali reflexo, limbo laterali et apicali angusto, sutura pro parte, duabus maculis parvis posthumeralibus transverse dispositis, macula tertia parva anteapicali sublaterali nigris, in dorso quinque-striata, striis nigro-guttulatis, haud punctatis, in lateribus etiam quinque-striata, striis levissime impressis, nigro-guttulatis. Pygidium (ठ) apice late rotundatum, ( + ) triangulare, apice extremo rotundatum, in utroque sexu grosse, in ( $q$ ) minus dense quam in $(\delta)$, punctatum.

Infra minute punctulatus ; $(\delta)$ abdominis segmentum anale apice grosse disperse punctatum, segmentum sextum distinctum ; suturis, macula obliqua laterali et plaga mediana metasternalibus, coxis, genibus, tarsis, nigris, femora et tibiae in utrisque lateribus nigro-marginatae.

ठ. Long (cap. excl.) $21 \mathrm{~mm}$., rostr. $9 \frac{1}{2}$, elytr. 9, lat. $9 \frac{1}{2} .^{*}$

+. " $, \quad 29, \quad, 14, \quad, 14, \quad, 14$.

Hab. Kina Baln (Brit. N. Borneo).

* The elytra of this and the following species of Curculionidae are measured from the base of the scutellum to the tip of the suture. 


\section{Omotemnus blandus sp. nov.}

\section{(Pl. XIII., fig. 6.)}

8 9. O. elongatus, sat depressus ; statura Rhynchophori, sed retrorsum sensim angustatus ; infra ater, abdomine obscure rubro, tibiis rubris; supra velutinus, flavo-ruber, nigro-signatus. Rostrum (ठ) rectum, apice vix arcuatum, magno dente triangulari apicali armatum, basi inter antennas sulco brevissimo fere punctiformi, antrorsum seriebus tribus tuberculorum, serie intermedia levissima, instructum, lateribus subtiliter unicarinatum, sine sulco distincto; (\$) arcuatum, parte anteantennali rugosum, quatuor sulcis versus basim incrassatam evanescentibus, et carina dorsali retrorsum gradatim excurrente antice sulco laevissimo instructa in tertia parte apicali subito abrupta, hic dentiformi; caput fovea interoculari profunda; antennarum articulus ultimus fulvo-ruber. Prothorax disco duabus plagis plus minusve magnis nigris, intus subrectis, extus subrotundatis, approximatis, notatus; (ठ) parum convexus, lateribus aequabiliter rotundatus, basi utrinque sat fortiter bisinuatus, infra (prosterno sparsim) dense granulatus, disco dispersissime punctulatus, punctis inconspicuis; ( + ) lateribus postice leviter rotundatus, fere rectus, dein antrorsum angustatus, basi utrinque sat fortiter bisinuatus, infra subtiliter dense granulatus (prosterno fere laevi), singulis punctis conspicuis regulariter dispositis, diseo dispersissime punctulatus. Scutellum basi punctatum, apice utrinque nigro-velutinum. Elytra sutura, omnibus marginibus, macula humerali plagaque laterali postmediana, cum macula humerali intus connexa nigris, dorso quinquestriata, striis antice inconspicne punctulatis, omnino minutissime granulosa, humeris punctatis. Pygidium disperse minute, in basi, praecipue in utrisque lateribus, dense fortius punctatum.

Femora dense granulata, supra pance punctata, postica (ठ) magno dente lato rotundato armata ; ( + ) tibiae anticae basi spina arcuata sat longa instruetae.

Long. (capite excl.) $60 \mathrm{~mm}$., rostr. 14, elytr. 25, lat. 23.

The black patches on the upperside vary in extent. Those of the elytron are usually connected by a longitudinal bar situated on the outside of the fifth impressed stripe; but in two examples these patches are not connected. The rostrum of the male has coarse but shallow punctures on each side close to the external rows of dorsal tubercles, each puncture bearing a small brush of rather strong and short hairs, which are so close together that the brush looks like one strong seta. The same brushes occur in both sexes on the upperside of the femora and on the base of the pygidium. The inner edges of the thighs, tibiae, and the margins of the last abdominal segment (dorsal and ventral part) are densely fringed with long orange rufous silky hairs. The tibiae have a very faint longitudinal depression.

Hab. Kina Balu (Brit. N. Borneo).

This form stands close to O. serrirostris (Fbr.), but is proportionally much longer ; the base of the prothorax is more produced towards the scutellum, and the basal sinus is much deeper. The rostrum of the male has a short groove between the antennae; the pronotum of the male is convexer than that of 0 . serrirostris, and the dilated, tooth-like part of the hind femora is rounded, not angulated. The rostrum of the female is rugose, not punctured, except the base, which bears a few fine punctures; the underside of the prothorax is densely granular even in the female; and the thighs are also thickly covered with granules in both sexes. Besides these differences in the structure, the new species will be easily recognised by the pattern of the pronotum. 
From O. Aleutiauxi Fst. and O. hauseri Fst. it may be at once differentiated by its size and colour, by the reddish last joint of the antennae, and by the prothorax being rather strongly bisinuated at each side of the base.

\section{Omotemnus conicus sp. nov.}

§. O. statura fere Cyrtotracheli; infra ater, tibiis fulvo-rubris; supra ruber, velutinus. Caput sat fortiter, in vertice dense, punctatum, fovea interoculari profunda. Rostrum basi fere rectum, in tertia parte apicali sat subito arcuatum, sulco laterali levi, sat brevi, sulcis dorso-lateralibus profundis, sed medium rostri vix attingentibus, carina mediana antrorsum gradatim crescente et deinde decrescente, in apice triangulariter impressa, retrorsum sulco profundo usque trans antennarum insertionem ascendente instructa ; basi sat dense, medio sparsim crasse punctatum, apice laevi, sulco mediano dorsali fortiter punctato. Antennarum articulus nltimus fulvo-ruber. Prothorax lateribus gradatim versus anticum attenuatus, lobo mediano basali sat producto, rotundato, basi utrinque bisinuatus, infra levissime granulatus (prosterno fere laevi), multis punctis regulariter dispersis, eorum margine infero elevato, tuberculiformi, instructus ; dorso disperse sed conspicue punctatus, basi medio impunctata excepta, linea media minime elevata, duabus plagis approximatis nigris, intus rectis, extus subrotundatis notatus. Scutellum nigro-velutinum, linea mediana inconspicue elevata, basi sparsissime granulata. Elytra quinque-striata, striis levibus, basi parum punctulatis, omnino minute disperse granulato-punctata; omnibus marginibus angnstis, plaga postmediana laterali elongata, maculaque hnmerali, nigris. Pygidium medio parum convexum, sat aequabiliter disperse punctato-granulatum, femora sparsim punctata; tibiae rubrae, levissime longitndinaliter impressae.

Long. (cap. excl.) $40 \mathrm{~mm}$., rostr. 11, elytr. 18, lat. $1 \%$

The exterior border of each puncture of the thorax is raised and forms an obvious granule; the punctures of the elytra and pygidium have the anterior border raised. The structure of the sides of the pro-, meso-, and metathorax is almost the same; the fine granules are a little denser on the metasternum, while here the granuliferous punctures are sparser. The hairs of the legs and last abdominal segment are of a blackish brown colour.

Hab. Barram River, Borneo (A. Everett).

In pattern this species is allied to the preceding one, but it has the outline of a Cyrtotrachelus, like O. ceylanensis Roel. and $O$. carnifex Fanst, from both of which it differs in colour, in the sculpture of the rostrum, in the outline of the prothorax, etc.

\section{Omotemnus gracilis sp. nov.}

+. O. forma Cyrtotracheli. Rostrum rubrum, arcuatum, versus apicem nigrescens, parte crassata basali disperse punctatum, inter antennas sulco minuto sat brevi instructum ; supra profunde bisulcatum, sulcis antennarum insertionem attingentibus, carina mediana separatis; hac carina antrorsum levissime elevata, ad apicem aequabiliter decrescente, in apice ipso bifurcata, retrorsum gradatim evanescente et medio fortiter confertim punctata, punctis confuentibus, sulcis dorsalibus rngulosis, versus basim parum punctulatis; lateribus profunde unisulcatum, sulco partem crassam basalem non attingente, sat subito abbreviato, sparsissime ruguloso-punctato. Caput fovea interoculari punctiformi profunda instructum, punctulatum. 
Antennae nigrae. Prothorax latitudine dimidio longior ; lateribus dimidio posteriore rectis, dein antrorsum subito convergentibus, angulatis ; basi versus scutellum rotundato-producta, utrinque levissime sinuata; obscure ruber, macula parva antemediana dorsali notatus, margine antico et marginis basalis medio nigris. Scutellum angustum, nigro-velntinum. Elytra retrorsum fortiter angustata, nigra, nigrovelntina, prothorace multo latiora; margine apicali prope suturam leviter emarginato ; omnino minute granulato-punctata, granulis in humeris densioribus ; singula elytra quinquestriata.

Prosternum dense granulosum, granulis medio sparsius sitis; processu intercoxali laevi, angusto, sulcato, parte postcoxali latitudine breviore, punctulata; nigro-rubrum, circum coxarum cavitates nigrum. Mesosternum nigrum, minute sat dense granulosum. Metasternum nigrum, episternis antice rubris, lateraliter subtiliter granulatum, medio dispersissime punctulatum. Abdomen nigrum, segmentis primo et quinto rubris, quinto apice et margine laterali angusto nigro, lateribus segmentis primo obsolete subtiliter granulato, secundo punctulato, tertio et quarto grosse, sed non dense punctatis, quinto grosse sat dense, in apice fortissime, passim irregulariter seriatim, haud dense punctato. Pygidium acntum, triangulare, medio apice carinatum, margine laterali apicali levissime reflexo, sat fortiter punctatum, punctis ad basim sparsis, versus apicem parum densioribus, nigrum, basi rubrum. Pedes rubri, coxis, femorum summa basi, genibus, tibiarum summo apice, tarsisque nigris vel brunneo-nigris; femora dispersissime punctulata; tibiae levissime sulcatae.

Long. (cap. excl.) 30, rostr. 8, elytr. 13, lat. 13.

Upperside clothed with a black velvety pubescence, without gloss; the dark reddish patches on the sides of the metasternum ill-defined; pubescence of the inner edges of the tibiae and of the under surface of the tarsi, ochreous ; pygidium without longer hairs at the apical margin.

Hab. Kina Baln (Brit. N. Borneo).

\section{Omotemnus niassicus sp. nov.}

ค. O. forma Cyrtotracheli; niger, lateribus metasterni et segmentorum abdominalium primi et ultimi parum rubescentibus, supra nigro-velutinus. Rostrum arcuatum; parte basali incrassata grosse sat remote punctatum, inter antennas breviter sed profunde sulcatum; dorso fortiter bisulcatum, sulcis ad basim evanescentibus, sed trans suleum interantennalem ascendentibus, carina mediana separatis, hac carina ante apicem gradatim minime elevata, dein decrescente et bifurcata, retrorsum in partem crassam basalem excurrente et grossissime rugato-punctata, sulcis dorsalibus parum rugulosis; lateribus etiam profunde sulcatum, sulco pance punctulato, infra et supra carina acuta marginato. Caput disperse punctatum, fovea sat levi interantennali signatum. Antennae nigrae. Prothorax latitudine tertia parte longior, lateribus dimidio postico rectus, sed sensim antrorsum convergens, dein versus apicem angustatus, obsolete punctatus, margine extremo laterali glabro grosse punctatum; basi ante scutellum rotundatus, utrinque vix emarginatus. Scutellum angustum, nigro-velutinum. Elytra retrorsum angustata, margine apicali prope suturam levissime sinuato, remotissime granulato-punctata (i.e. punctorum margine antico elevato), granulis in humeris densioribus; quinquestriata, stria quinta fortissime abbreviata.

Prosternum minute granulosum, singulis punctis instructum, granulis versus medium obsoletis; processus prosternalis parte postcoxali longitudine latiore. 
Meso-metasternum, abdomenque dispersissime punctulata, punctis in lateribus abdominalium segmentorum tertii et quarti densius sitis; segmento apicali abdominali apice grossissime punctato, lateribus dense grannlato-punctatis. Pygidium triangulare, apice ipso rotundato, in linea mediana leviter convexum, omnino sat grosse dense punctatum. Pedes sparsim punctulati, tibiae extus inconspicue sulcatae.

Long. (cap. excl.) 24 mm., rostr. 7, elytr. 11, lat. 10.

The base of the rostrum has a rather deep curved impression behind the antennal grooves; the lateral sulci of the rostrum are deep and almost reach the antennal grooves ; the sides of the prothorax are faintly angular in front of the middle ; the punctures of the pygidium large, but smaller than the interstices between them ; each puncture bears an extremely short brush of hairs, which is visible only with a strong lens and almost looks like a yellowish scale.

Hab. Nias I. (I. W. Thomas).

Differs from 0 . gracilis sp. nov. in colour, in the less angular sides of the prothorax, in the elytra being proportionately narrower at the base, in the form and structure of the pygidium, structure of the under surface, and some minor characters.

\section{Omotemnus compressirostris sp. nov.}

3.?. O. forma Cyrtotracheli; nigro-ruber vel atro-purpurens, supra nigrovelutinus; rostro pro maxima parte, antennis (articulo ultimo brunneo excepto), prothoracis limbo angusto basali, elytrorum margine basali, humeris, macula laterali postmediana, prosterni medio, mesosterno (macula magna laterali rubra excepta), metasternalis episterni apice, abdominalium segmentorum $2^{\mathrm{i}}, 3^{\mathrm{il}}, 4^{\mathrm{i}}$ margine apicali angustissimo, coxis, genibus, tibiarum apice extremo, tarsisque nigris vel atris ; interdum colore atro rostrum, elytra, prosternum, mesosternum, abdominis segmenta intermedia pygidiumque pro maxima parte occnpante.

Rostrum (ठ) basi subrectum, apice sat fortiter curvatam, dorso profunde nnisulcatum, sulco ipso sublaevi, foveam interocularem attingente, duabus seriebus tuberculorum armatum, basi in ntroque latere juxta tuberculorum series sulco subdorsali levi instructa, omnino sat disperse singulatim, passim parum densius, punctatum; ( $($ ) aequabiliter sat fortiter arcuatum, basi sicut in ( $\delta$ ) levissime incrassata dorso sparsim, lateribus densius punctata, sulco dorsali mediano ut in (ठ)), parum rugato, longitrorsum juxta suleum dorsalem sat fortiter rugato-punctatum, praeterea ante basim et in apice utrinque sulco levissimo subdorsali instructum; in utroque sexu apex rostri compressus, in dorso lamelliformis, sulco dorsali rostri pone hane carinam lamelliformem evanescente, hac carina emarginatione sat lata divisa in partes duas, parte posteriore in (ठ) sat elevata tuberculiformi, in (₹) longiore, minus elevata, parte anteriore rotundata, parum trans mandibularum apicem producta. Caput fovea interoculari sat profunda parum transversa notatum, singillatim sat disperse, ad marginem postico-dorsalem oculorum densius, punctatum.

Prothorax ante scutellum rotundato-productus, utrinque leviter emarginatus, lobo antescutellari in (ठ) plus quam in ( $(+)$ rotundato ; (ठ) fortiter convexus, lateribus pone strangulationem apicalem fortiter ampliato-rotundatus, dein usque ad angulos basales levius, sed sensim rotundatus, in medio latior quam in basi, punctis minutissimis in medio disci sparsissimis, versus latera et basim parum densioribus instructus; ( $)$ pone strangulationem apicalem rotundato-ampliatus, dein usque ad basim fere rectus, latitudine in basi vix majore quam in medio, dorso 
leviter convexus, sparsissime levissime, versus latera parum sensius punctulatus. Scutellum sat breve et latum, lateribus retrorsum minime convergentibus, in apice extremo sat fortiter rotundato-convergentibus. Elytra versus apicem (ठ) fortiter, ( $q$ ) parum minus, angustata, in basi prothorace ( $\delta$ ) circiter quinta, $(q)$ quarta parte latiora, apice singulo rotundato, angulo suturali subrecto; quinquestriata, lateribus sparsim punctulata, sine striis obsoletis.

Prosternum processu postcoxali longitudine paulo latiore, (ठ) densissime minute granulatum, granulis in medio minutissimis, $(q)$ nonnullis punctis minutis dispersis instructum, medio vix punctulatum. Mesosternum (ठठ \&) lateraliter sicut prosternum sculpturatum. Metasternum et segmenta duo basalia abdominalia (ठ) indistincte granulosa, praeterea disperse punctulata nt in ( $\uparrow)$, medio (ठ) longitrorsum depressa vel impressa; caetera segmenta abdominis lateraliter, quintum etiam ad totum marginem apicalem grosse, in $(\delta)$ densius quam in ( $q$ ) punctata ; segmentum quintum (ठ) apice late rotundatum, (₹) triangulare, apice extremo parum rotundatum. Pygidium ( $\delta$ ) apice depressum, basi medio leviter convexum, lateraliter longitrorsum levissime impressum, apice rotundato-truncatum, ( $\uparrow)$ triangulare, apice hand depressum, lateraliter levissime impressum; in utroque sexu sat disperse, in basi vix densius quam in apice punctatum.

Femora antica (ठ) dense granulosa, supra nonnullis punctis instructa, ( + ) intus disperse punctata, extus disperse punctulata. Tibiae in ntrisque lateribus distincte, in (ठ) sensius quam in ( $\%$ ), sulcatae, posticae ( $\left.\delta^{\circ}\right)$ basi margine interno parum carinatae, hand dentatae. Pili femorum, tibiarum, tarsorum (infra) ferruginei.

Long. (cap. excl.) $29 \mathrm{~mm}$., rostr. 10, elytr. 13, lat. 13.

From the other cyrtotracheloid species of Omotemnus this form differs chiefly in the form and sculpture of the rostrum of both sexes, and in the strongly convex prothorax of the male.

Hab. Assam (Khasia Hills) and Upper Burmah (Ruby Mines).

One male specimen from North India, probably from Sylhet, has the prothorax rather more convex, and the pygidium much more densely punctured at the sides than along the middle; the punctuation on the sides of the second abdominal segment is also coarser and denser than in typical specimens.

In one female example from the Khasia Hills (Assam) the base of the trunk is as sparsely punctured on the sides as on the upperside.

These two forms are only aberrations, I believe, of the above-described species, with which they agree in all other characters.

\section{Roelofsia borealis sp. nov.}

$$
\text { (Pl. XIII., fig. 7.) }
$$

J f. $R$. lateritia ; rostro (basi supra excepta), prothorace limbo antico, macula fere semicirculari sat magna antescutellari, parte postica prosterni, scutello, elytris (regione scutellari excepta), pygidio macula apicali, meso-metasterno abdomine pedibusque nigris vel brunneo-nigris; meso- et metasterno et abdomine lateribus lateritio-maculatis, femoribus et tibiis quatuor posticis basi apiceque exclusis lateritiis.

ठ. Caput punctis sat magnis modice dense tectum, sulco interoculari punctiformi profundo ; rostrum rectum, apice leviter dilatatum, supra planatum, utrinque serie tuberculorum instructum, sparsissime punctulatum, minutissime 
rngulosum, sublaeve, punctis in parte dilatata apicali distinctioribus. Prothorax longitudine sexta parte brevior, subglobosus, lateribus postice fere rectus, in tertia parte antica sat subito antrorsum attenuatus; basi ante scutellum leviter rotundato-dilatatus, utrinque parum sinnatus; minutissime punctulatus, obsoletissime rugulosus, dispersis punctis, versus latera sensius, instructus. Scutellum triangulare, lateribus minime incurvatum, apice acutum, basali dimidio punctatum, apice laeve. Elytra retrorsum attenuata, angulo suturali dentata, quinquestriata, striis $6^{\mathrm{a}}-9^{\mathrm{a}}$ lateralibus postice sat distinctis, in interstitiis sparsissime sensim, postice densius, punctulata, lateribus obsoletissime rugulosa.

Prosternum fortiter granulosum; processu medio postcoxali valde bilobato. Metasternum sparsissime punctulatum, sulco mediano interdum antice rugatopunctato instructum. Abdomen disperse obsolete punctulatum, punctis in segmentorum basi et lateribus densioribus majoribus ; segmentis tertio ad quintum lateraliter spatio sat grosse punctato; segmentum quintum parte dorsali subpygidiali fortiter punctatum. Pygidium convexum, apice fortiter declive et rotundatum, hand marginatum, linea media impressa, lateribus dense, medio vix sparsius sed minutius punctatum.

Pedes antici valde elongati, femoribus basi curvatis, tibiis apice fortius quam basi areuatis.

. Caput fortius quam in mare punctatum ; rostrum supra leviter tricarinatum, carina media obtusa, lateribus subcarinatum. Prothorax et elytra sensius punctulata quam in mare. Pygidium subacute triangulare.

$\delta$ Long. (cap. excl.) 39 mm., rostr. 15, elytr. 20, lat. 18.

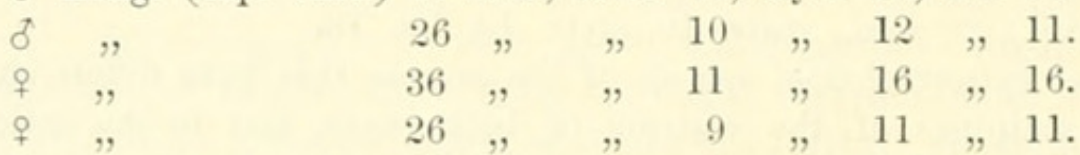

The brick red colour of this species varies much in extent, and occupies the whole upperside of the elytra in many specimens; the basal black spot of the prothorax is sometimes very feebly marked. The sides of the meso- and metasternum are brick red with the sutures black; the last abdominal segment, which usually is black in large males, is of a brick red colour in smaller males and in females, except the tip, which is blackish. The punctuation of upperside is stronger in small specimens and in females than in large males.

In structure this form is more closely allied to $R$. buqueti (Guér.) than to $R$. dux (Boh.); in the length of the rostrum, and the ontline of the elytra it stands between these species, from both of which it is distinguished by the bright brick red colour of the prothorax.

The rostrum is less dilated at the tip and proportionally shorter than in $R$. dux , but somewhat longer than in $R$. buqueti. The prothorax is shaped almost as in $R$. buqueti, but a little more convex, while the elytra are longer than in this species and resemble more those of $R$. dux. The anterior tibiae of the male have the form of those of $R$. buqueti.

From R. dichrous (Fairm.) (Ann. S. E. Fr., 1878, p. 273) it differs in colour, in the form of the anterior femora of the male, "these femora being almost straight, and a little arched at the base" in $R$. dichrous, in the prosternum being granular in $R$. borealis, and not punctured as in $R$. dichrous, in the punctuation of the elytra being more distinct on the sides in $R$. dichrous, while in $R$. borealis the sides of the elytra have iscarcely any distinct punctures.

Hab. Omei-Shan (China). 


\section{Otidognathus collaris sp. nov.}

(Pl. XIII., fig. 8.)

8. O. ater; prothorace plaga maxima discoidali, ante basim emarginata, antice usque constrictionem apicalem extensa recta, elytris (limbo sat lato apicali excepto), maculaque laterali mesosternali, rubro-rufis. Rostrum rectum, dorso inter antennas utrinque sulculo inconspicuo instructum et punctatum, dein longitrorsum biseriatim tuberculatum, linea mediana pro certa lnce evidenter elevata, apice subcordiformi dilatato-striatum, lateribus sat dense punctulatum, subtilissime rugulosum. Caput crassissime confertissime punctatum, fovea interoculari rotunda sat magna; oculis approximatis. Prothorax antice fortiter constrictus, pone constrictionem valde rotundato-ampliatus, maxima latitudine ad basim, subconvexus, lobo antescutellari late rotundato utrinque haud sinuato ; punctis magnis et minutissimis dorso irregulariter sat disperse, infra latera densius fortiusque instructus, lobo basali sulco irregulari transverso grosse punctato. Scutellum basi crasse punctatum. Elytra dorso profunde quinque-punctato-striata, lateribus quatuorseriato-punctata, his seriebus postice, nona tota, impressis, praeterea serie subhumerali brevi, interstitiis dorso levissime elevatis, sparsissime punctulatis, lateribus hand elevatis, punctis magnis instructis. Pygidium triangulare, apice subtruncato-rotundatum, medio costato-elevatum, margine apicalis reflexo, fortissime subumbilicato-punctatum.

Prosternum medio dense punctulatum, punctis levissime impressis, processu postcoxali fortiter bilobo. Meso- et metasternum lateribus punctis magnis sat densis, medio minutis sparsis. Abdomen lateribus fere sicut metasternum punctatum, segmento ultimo punctis pro parte confluis; medio sat fortiter sed remote punctatum, punctis in segmentis primo et quinto densioribus. Femora disperse punctata.

Long (cap. excl.) $14 \mathrm{~mm}$., rostr. 6, elytr. 6, lat. $7 \frac{3}{4}$.

The basal lateral angle of the first abdominal segment, and the extreme tip of the metasternal epipleura are of the red colour of the elytra; the last abdominal segment shows also a faint reddish tint at the apex. The punctuation of the under surface is very strong on the sides.

Hab. Java.

\section{Otidognathus pygidialis sp. nov.}

б. . O. ochraceo-rufus, nigro-signatus; abdomine nigro, ochraceo-rufo-maculato. Rostrum nigrum, levissime areuatum ; (ठ) parte basali parum incrassata rugatopunctatum, medio canaliculatum, deinde supra biseriatim tuberculatum, inter has series ruguloso-granulatum, apice extremo laeve; lateribus indistincte sulcatis, sparsissime punctulatis; ( + ) cylindricum, omnino disperse minute punctulatun. Caput nigrum, interoculari fovea sat parva instructum, fortiter dense punctatum. Prothorax $(\delta)$ antrorsum subgradatim attenuatus, lateribus parum rotundatis ; ( $q$ ) pone constrictionem apicalem parum latior quam in mare, basi ante scutellum dilatatum, parte dilatata utrinque vix emarginata ; fortiter sat dense, in medio sparsius minute punctatus, fascia mediana seu ab margine antico usque ad disci medium extensa, seu completa, basim attingente, sed parte basali angustata, praeterea macula basali laterali sat parva, interdum inconspicua, nigris notatus. Scutellum nigrum, angustum, basi extrema punctatum. Elytra retrorsum sensim attenuata, novemstriata, striis quinque internis minute, tribus externis fortiter dense punctatis, 
interstitiis etiam fortiter dense, versus basim sparsius, punctatis, macnla basihumerali, duobus punctis vel maculis posthumeralibus, uno laterali, uno dorsali, macula mediana prope snturam sita, macula postmediana laterali, interdum cum macula mediana connexa, limbo apicali ad suturam dilatato, nigris.

Prosternum medio nigrum, disperse punctulatum, punctis lateribus majoribus. Mesosternum nigrum, in utroque latere ochraceo-bimaculatum, episternis fortissime punctatis. Metasternnm fascia sat lata mediana et margine apicali nigris, medio sparsim punctulatum, lateribus punctis magnis sat profundis passim irregulariter seriatim dispositis instructum. Abdomen nigrum, segmentis primo, secundo, quarto macula laterali ochracea notatis, quinto ochraceo-trimaculato, lateribus, praecipue segmentorum tertii et quarti grosse punctatum. Pygidium triangulare, medio retrorsum fortiter carinato-elevatum, carina apice rotundata sat prominente, grossissime punctatum, limbo laterali anguste nigrum. Pedes ochraceo-rufi, femorum basi et margine superiore, genibus, tibiarum apicibus extremis tarsisque nigris.

8. Long (cap. ex.) $10 \mathrm{~mm}$., rostr. 4, etytr. 4, lat. 5.

+. , ( , ) $16, \quad, \quad 6 \frac{1}{2},, \quad 6 \frac{1}{2},, 8$.

The median black band of the prothorax, the basal spots of the latter and the marks of the elytra vary in extent, and in one specimen there is a second black spot in the middle of the sides of the prothorax. The marks are arranged as in $O$. davidis Fairm., to which the new species bears a close resemblance. O. davidis is, however, usually a little larger, the rostrum of the male has three rows of tubercles, whilst in 0 . pygidialis sp. nov. the median row is reduced to faint and irregular rugosities; the antescutellar lobe of the prothorax, which is very broad and entirely rounded in $O$. davidis, has the sides faintly sinuate in $O$. pygidialis, so that the lobe appears to be longer and narrower in the latter species; the pygidium has usually a blackish and feebly raised middle line in $O$. davidis, and bears an impression on the apex, whilst it is strongly carinate in $O$. pygidialis. The mesosternum has two ochreous rufous spots on each side in 0 . pygidialis, the metasternum has a black median band, and the fifth abdominal segment bears three ochreous rufous maculae; in $O$. davidis, on the other hand, the mesosternum has one lateral spot, the black median band is absent from the metasternum, and the last segment of the abdomen is marked only with two large ochreous rufous spots.

Otidognathus nigropictus Fairm. is another species to which 0 . pygidialis sp. nov. is allied; but the prosternum of $O$. nigropictus has two black longitudinal bands, the metasternum is black, with three yellowish patches, and the black abdomen has only one yellow spot on each side of the last segment, the interstices of the stripes on the elytra are almost smooth, and the pygidium is not carinate.

O. comptus (Pasc.) from Cambodja is also similar in size and colour to O. pygidialis, but is distinguished from the new species by the differently spotted elytra, the colour of the last abdominal segment which is red with the apical third black, and by the convex interspaces between the stripes of the elytra, the dorsal ones of which are scarcely punctured.

Hab. Kinkiang (China).

Of $O$. dacidis Fairm., the Tring Museum contains a number of entirely black specimens from Omei Shan (China).

\section{Allogaster niger sp. nov.}

8. A. omnino niger, vix nitens, pilis erectis nigris vestitus, abdomine plagis transversis brunneo-nigro-pilosis, tars infra lntescente-pubescentibus. 
Caput dense grosse punctatum, inter antennas profunde canaliculatum, vertice medio spatio parvo laevi instructum. Antennae corpore plus duplo longiores, scapo dense punctato. Prothorax rugato-punctatus, disco subreticulatus, latitudine vix brevior, subrectangularis, lateribus inconspiene rotundatus, medio dente brevi subspiniformi parum versus posticum directo armatus, dorso ante medium utrinque subtuberculatus, medio ipso etiam levissime elevatus. Scutellum rotundatum, vix triangulare, punctatum, apice impressum. Elytra apice subtruncato-rotundata, rudissime confertissime punctata, singulo disco in dimidio basali bi-, in dimidio apicali uni-subcostato.

Infra grosse punctatus. Femora et tibiae longitrorsum subsulcata, postica abdominis apicem subattingentia.

Long. 20 mm., elytr. 14, lat. $5 \frac{3}{4}$.

Hab. Benue River (W. Africa).

Very peculiar as regards the entirely black colour.

\section{Stromatium hirsutum sp. nov.}

8. S. nigro-brunneum, infra leviter nitidum, supra opacum, omnino pilis erectis hirsutum, praeterea sat sparsim flavescente-pubescens, pube in prothorace et elytris plus minnsve seriatim disposita. Caput et prothorax subreticulato-rugati. Antennae corpore paulo longiores, fortiter-praecipue articulis tribus basalibus-rugatopunctatae, articulo secundo sat longo. Prothorax longitudine latitudini aequali, convexus, lateribus rotandatus ; disco levissime depresso tuberculis duobus minutis medianis nitidis instructus. Scutellum rotundatum, dense flavescente-pubescens. Elytra prothorace hand latiora, fortissime rugato-punctata, in singulo disco duabus lineolis medianis brevibus approximatis pallide ochraceis notata; singulo apice extus fortiter rotundato, angulo suturali valde obtuso.

Caput infra transverse striatum et rugatum. Sterna fortiter rugato-punctata ; metasternum medio longitudinaliter profunde sulcatum; processu prosternali non elevato pone coxas fortiter declivi parum impresso, mesosternali sat lato, declivi, medio parum impresso. Abdomen fortiter, medio minus dense, punctatum. Pedes ruguloso-punctati, femoribus infra rugatis, posticis apicem segmenti tertii abdominalis attingentibus.

Long. 16 mm., elytr. 11, lat. 4 .

The structure of the derm of this species is very coarse. The elytra have two raised stripes each, the middle parts of which are more elevate, smooth, and of a pale ochreous colour.

Hab. Kayes (Senegal).

\section{Clytosaurus siamensis sp. nov.}

(Pl. XIII., fig. 9.)

Cl. niger, pube flava ornatus. Caput fronte perpendiculari planatum, grosse punctatum, flavum, vitta mediana frontali antice abbreviata, vitta anteoculari indistincta, nigris. Antennae rufo-ochraceae, versus apicem fulvae, elytrornm medium attingentes; scapo dense punctulato, articulo tertio crassiore, quinta parte breviore. Prothorax subglobosus extrema basi fortiter strangulatus, dorso medio longitrorsum elevatus, mox pone marginem anticum subtuberculatus, in medio ipso transversa carina brevi instructus, omnino rugatus, in utrisque lateribus arenatim impressus, aren sat lato mox pone medium lateris incipiente oblique versus dorsum et basim ascendente, constrictionem basalem hand attingente; flavo-pubescens, 
elevatione longitudinali dorsali (ni marginem anticum ni basalem attingente), fascia transversa irregulari laterali areum impressum antice marginante, infra latiore, in medio lateris versus anticum dilatata, cum fascia dorsali confluente, macula areuata pone arcum impressum sita, nigris. Scutellum triangulare, dense flavo-pubescens. Elytra prothorace non latiora, retrorsum parum angustata, singulo apice truncato, angnlis levissime dentatis, densissimetransverse ruguloso-punctata, nigro-pubescentia, signaturis flavis ornata: macula magna humerali, versus suturam angulata fasciam brevem humeralem nigram includente, a scutello et sutura fascia anguliformi nigra separata, fascia postbasali transversa, in disco utriusque elytri angusta et recta, ad marginem lateralem usque ad medium descendente, juxta suturam (in sutura ipsa interrupta) valde versus scutellum, minus versus posticum dilatata, his partibus dilatatis ntrinsque elytri simul sumtis maculam fere rhomboidalem formantibus, fascia valde arcuata ab quarta parte postica suturae trans medium disci ascendente, hinc versus latera recurrente marginem lateralem in tertia parte apicali tangente, in disco latiore, fascia anteapicali, in sutura non interrupta, parum areuata, in sutura et margine laterali cum areu flavo postmediano connexa, versus latera angustata ; apice flavo-pubescente.

Corpus infra flavo-pubescens, suturis, metasterni medio, segmento nltimo abdominali fere nigris. Pedes rnfo-ochracei, femorum parte incrassata fulva, sat sparsim flavo-pubescentes.

Long. 21 mm., elytr. 14, lat. $5 \frac{1}{2}$.

Clytosaurus priapus Thoms, which I have not seen, must be a similarly coloured species with black legs; but according to Thomson's description (Syst. Ceramb., p. 190) the head of his species has four spots, and the prothorax is rough only in the middle of the base, while it is rugose all over in the new insect; of the elytra Thomson says nothing but: elytra maculis 8 angularibus aut flexuosis.

Hab. Siam.

\section{Acrocyrta reticulata sp. nov.}

A. nigra. Caput sparsim griseo-pubescens, minute dense ruguloso-granulatum ; frons planata, minuta carina mediana instructa. Antennae basi (articulis $1^{\circ}-2^{\circ}$ totis) rufae, versus apicem subnigrae, sparsim, apice densius, albo-tomentosae ; scapo crasso, dense punctulato, parum arcuato; articulo tertio quarto et quinto simul sumptis vix breviore, $8^{\circ}-10^{\circ}$ brevibus, aequalibus, tertio et quarto apice tenuiter spinosis. Prothorax fere subglobosus, lateribus aequabiliter rotundatus, basi constrictus, sat fortiter reticulatus, basi utrinque macula dense niveo-pilosa signatus. Scntellum album. Elytra parallela, apice singulatim parum oblique truncata, intus et extus breviter spinosa ; dense minutissime punctulata, nigrotomentosa, duabus fasciis transversis niveis ornata, prima signatura postbasali margines externos hand attingente in utrisque elytris parum areuata sagittiformi, secunda etiam angusta, in sutura latiore quam ad margines externos, fere recta, postmediana.

Meso- et metasternum abdominisque segmenta basalia macula laterali nivea notata. Pedes nigro-rubri, antici ut omnes tarsi rufi.

Long. 5 mm., elytr. $3 \frac{3}{4}$, lat. 1 .

Antennae extending a little beyond the middle of the elytra, rufous, with the tip of third to tenth joints becoming more and more blackish. Prothorax slightly longer than broad, narrower at the base than at the apex; the basal spot on each side of a snowy white pubescence, transverse, ending above the coxal cavities. The 
first mark of the elytra standing at the end of the first quarter, eurved on each elytron; the second band situated before the beginning of the apical quarter, narrow on the sides, where it is a little curved towards the front.

Hab. Kina Balu (Brit. N. Borneo).

Allied to A. collaris Pasc., but differs from that species in the more globose and obviously reticulated prothorax, in the form of elytral white bands, in the apex of the elytra being devoid of white pubescence, and in the colour of the legs.

\section{Arcyphorus reticulatus sp. nov.}

+. A. niger, vittis pube sulfurea obtectis ornatus. Caput fronte leviter tricarinatum, carina media antice abbreviata, linea transversa impressa antefrontali anguliformi, in verticis medio et post oculos punctis magnis instructum. Antennae articulis basi rufis, apice subnigris, pube grisea vestitis, corporis dimidio paulo longiores, articulo tertio quinto longiore. Prothorax oblongus, antice et postice truncatus, convexus, ad basim parum constrictus, lateribus aequabiliter rotundatus, subtiliter reticulatus, sulfureo-pubescens, fasciis tribus latis ni basim ni apicem attingentibus una mediana, una in utroque latere sita, nigris ornatus. Scutellum fere semicirculare, sulfureo-pubescens. Elytra prothorace vix latiora, versus posticum parum attenuata, apice singulo subrotundata, minutissime punctulata, praeterea punctis dispersis majoribus instructa, punctis pube densa celatis ; sutura sat late sulfureo-pubescente, hac vitta suturali elytris communi post medium interrupta et ante hane interruptionem anguste usque fere ad margines externos dilatata ; singulo elytro linea discoidali, vittae suturalis colore, suturae parallela et ad marginem basalem cum ea connexa, ab basi ad medium ascendente signato.

Infra lateraliter dense, in medio sparsim griseo-pubescens. Prosternum antice transverse striatum, dein reticulatum. Femora nigra, intermedia parte incrassata subtus bicarinata, postica abdominis apicem attingentia; tibiae anticae et omnes tarsi subrufi.

Long. $11 \mathrm{~mm}$., elytr. 8, lat. $2 \frac{1}{2}$.

The black parts of the upperside between the sulphur yellow markings covered with a brownish black pile, which conceals the punctuation of the elytra; the pubescence of the head, antennae, under surface and legs grey ; head and prosternum clothed with sparse long hairs. The lateral keels of the front of the head slightly flexnose and stronger than the median one, which bears a fine channel between the eyes. The fourth antennal joint abont two-thirds the length of the fourth. Prothorax evenly oval, longer than broad, with an obvious reticulation ; the black bands broader than the sulphur yellow ones, and reaching neither the anterior nor the posterior border. Apex of each elytron obliquely rounded at the suture, and very feebly acuminate externally. Base of the femora, and the four posterior tibiae slightly reddish, anterior tibiae and all tarsi dark rufous.

Hab. Kina Balu (Brit. N. Borneo).

\section{Acrocyrtidus gen. nov. (Compsocerinorum).}

+. Cavitatibus intermediis apertis, coxis anticis extus angulatis, processum prosternalem medio sulcatum, postice areuatum et parum dilatatum vix superantibus. Palpis articulo ultimo triangulari ; clypeo et frontis parte antica subtriangulariter depressis ; genis oculorum lobo inferiore brevioribus; tuberibus antenniferis brevibus, distantibus ; oculis profunde sinuatis, lobo superiore parvo ; antennis (q) corpore aequalibus, scapo levissime arcuato, versus apicem minime incrassato, articulo tertio 
scapo duplo longiore, $4^{\circ}-9^{\circ}$ subaequalibus, $10^{\circ}$ et $11^{\circ}$ brevioribus, $3^{\circ}-6^{\circ}$ apice extus breviter spinosis; prothorace longitudine latitudini aequali, inermi, antice et postice subconstricto, lateribus subrotundatis ; scutello transverso, apice rotundatotruncato; elytris basi rectis, retrorsum parum angustatis, apice singulis oblique rotundato-truncatis, humeris rotundatis parum prominentibus, dimidio basali in disco planato, lateribus perpendicularibus, dimidio posticali in disco et lateribus subconvexo; processu mesosternali lata, declivi; pedibus gracilibus, femoribus versus apicem levissime incrassatis, postice elytrorum apicem superantibus; tarsorum posticorum articulo primo $2^{\circ}$ ad $4^{u m}$ longitudine aequali.

Type: Acrocyrtidus fasciatus sp. nov.

The species for which I have to propose this new genus bears a close resemblance in the pattern of the elytra to some species of Acrocyrta Pasc. (p. e. A. tenuispinosa Pasc.), but it does not fit into the group "Clytides" as the anterior coxae are angular exteriorly, nor into the group "Hétéropsides" as the intermediate coxal cavities are open. It will be placed best after Callichromopsis in the group "Compsocérides" with which it agrees in the open intermediate coxal cavities, angular anterior coxae, triangular last joint of the maxillary palpi, shortly spined intermediate joints of the antennae, and other characters.

\section{Acrocyrtidus fasciatus sp. nov.}

(Pl. XIII., fig. 10.)

ๆ. A. niger, dense cinereo-pubescens, pube totam sculpturam obtegente. Palpi brunnei. Elytra fasciis tribus nigris ornata, prima postbasali in utrisque elytris ab margine laterali parum oblique versus suturam descendente, juxta suturam angustata, in sutura ipsa usque ad scutellum ascendente, hac parte postscutellari recta ; fascia secunda mediana in disco utriusque elytri antrorsum dilatata, hac parte versus suturam eurvata ubi angustata, suturam in tertia parte basali attingente; fascia tertia recta, in sutura parum angustiore, in tertia parte apicali sita.

Long. $15 \mathrm{~mm}$., elytr. 11, lat. $3 \frac{1}{2}$.

The median band of the elytra tonches the suture only before the middle, and resembles somewhat a mitre.

Hab. Siam.

\section{Tmesisternus dohertyi sp. nov.}

(Pl. XIII., fig. 11.)

T. ater. Caput tomento viridi-caeruleo metallico vestitum, medio longitudinaliter profunde sulcatum, prope antennarum tuberes leviter impressum, perpaucis punctis instructum, occipite utrinque macula aurata splendida ornatum. Antennae corpore quarta parte breviores, articulo tertio quarto longiore. Prothorax transversus, in basi latior quam in apice, basi utrinque sinuatus, ante scutellum minute emarginatus, dente infralaterali sat parvo, dorso lateribus medio parum impressus, pone marginem anticum tuberculo obtuso armatus, disci medio laevis, lateraliter crasse punctatus ; viridi-caeruleo-tomentosus, dorso plaga magna laterali ferrugineo-sericea ornatus. Scutellum rotundatum, apice parum depressum, lateraliter dense punctulatum, linea mediana laevi, apice tomento elytrorum basis. Elytra apice truncata, angulo externo valde rotundato, suturali minime producto ; sparsis punctis magnis instructa, punctis in medio dimidii apicalis singuli elytri et in basi prope humerum densioribus ; fascia basali ab scutello oblique ad marginem exteriorem posthumeralem descendente, totam basim intra humerum et scutellum occupante, fascia mediana sat recta, fascia postmediana ab suturae tertia parte apicali valde oblique 
ad marginem externum descendente, margine suturali, plagaque irregulari magna apicali laete viridi-aureis, splendidis, passim caernlescentibus.

Infra viridi-caeruleo-sericans, metasternum postice utrinque macula rufo-ferrngineo-sericante notatum ; tibiae apice pube luteo-ochracea vestitae.

Long. 28 mm., elytr. 20, lat. 9.

The pubescence has a highly peculiar metallic gloss, which will at once differentiate this species from the other forms of "Tmésisternides." The species comes near T.yorkensis (Fairm.) in size and shape.

Hab. Humboldt Bay (New Guinea) (IV. Doherty).

\section{Cornuscoparia gen. nov.}

A genere Sarothrocera White differt: Oculis lobo inferiore valde elongato, latitudine fere duplo longiore; antennis (ठ) corpore plus duplo longioribus, infra dense, sed minus longe quam in Sarothrocera ciliatis, prothorace antice et postice transverse sat profunde sulcato, elytris singulis apice oblique truncatis, tibiis apice haud compresso-dilatatis.

\section{Cornuscoparia ochracea sp. nov.}

o. C. nigra, dense ochraceo-pubescens, antennis articulis $5^{\circ}-11^{\circ}$ totis, et $3^{\circ}$ et $4^{\circ}$ apice nigro-pubescentibus, elytris fascia longitudinali obliqua humerali et duabus fasciis transversis anguliformibus, una antemediana, secunda mediana (㐱, denudatis signatis.

Caput longitrorsum canaliculatum ; fronte rectangulari ; tuberibus antenniferis approximatis, apice denudato remote punctatis. Antennarum scapus conicus, versus apicem sat fortiter incrassatus. Prothorax longitudine parum latior, rectangularis, antice et postice fortiter sulcato-constrictus, dente laterali conico valido armatus, disco utrinque et pone dentem lateralem pancis punctis nigris notatus. Scntellum latitudine multo longins, apice rotundatum. Elytra grosse punctata, punctis tomento obtectis, fascia denndata humerali grossissime punctata, latitudine plus duplo longiora, ad tertiam partem apicalem subparallela, dein rotundato-angustata, basi subrecta, intra humeros parum impressa, humeris rectis, angulo tuberculo levi instructo, lateribus sub humeros perpendicularia, hac parte perpendiculari supra fascia nigra marginata, triangulari ; apice singulo breviter oblique truncato, angulo externo recto, fere acuminato, interno subrotundato.

Femora postica segmenti quinti abdominalis basim attingentia.

Long. 33 mm., elytr. 24, lat. 11.

The transverse angular bands of the elytra are inconspicnous, and perhaps quite absent from specimens in perfect condition.

Hab. Dorey (Dutch N. Guinea).

\section{Acroama gen. nov.}

Tuberibus antenniferis verticalibus, contiguis, singulo antice tubereulo apicali versus inferum directo armato. Antennis fere glabris, scapo apice subito incrassato, elytrorum basim attingente, articulo tertio longiore, tertio quarto minute breviore. Prothorace cylindrico, latitudine longiore. Elytris cuneiformibus, humeris rectis, prothorace duplo latioribus, apicibus singulis longe acuminatis, singulo elytro basi tuberculo sat valido armato. Femoribus clavatis, posticis abdominis segmenti tertii medium attingentibus.

This genus is very remarkable as regards the form of the antennal tubers, scape of antennae, and elytra. It is to be placed after Smermus Lac. 


\section{Acroama armata sp. nov.}

8. A. nigro-brunnens, pube brevi sat sparsa flavescente vestitus. Caput minute punctulatum, praeterea omnino punctis magnis dispersis instructum, vertice medio pone tuberes antenniferos parum depressum. Antennae corpore sesqui longiores, rubrae, scapo basi extrema et apice incrassato nigro, caeteris articulis versus apicem plus minusve nigrescentibus; scapo dense punctulato, parte lapicali nigra laevi. Prothorax longitudine tertia parte brevior, cylindricus, basi apice minime latiore, grossissime punctatus, irregulariter transverse rugato-plicatus, disci medio distincte depressus, ante basim impressns. Scutellum subtrapezoidale, latitudine (ad basim) parum brevius. Elytra brunnea, angulo humerali, tuberculo hasali, acumine apicali, nonnullis signaturis indistinctis, nigris : macula posthumerali longitudinali, cum macula humerali connexa, gutta postbasali discoidali, fascia valde obliqua ab sutura ante medium ad marginem exteriorem descendente, fascia secunda, primae parallela, postmediana, in singulo elytro interrupta ; singulo elytro ad suturam (basi excepta) impresso, disci medio etiam parum depresso ; grosse, versus apicem sparsius, punctata, impressione suturali postice laevi ; angulo suturali minuto, subrotundato, acumine apicali conico, acuto.

Prosternum grosse punctatum, processu pone coxarum cavitates triangulariter dilatato, ubi processu mesosternali latiore; mesosternum medio paucis punctis magnis instructum ; latera mesosterni et metasterni grossissime punctata, metasternnm medio minutissime punctulatum fere laeve; abdomen laeve, segmentis basalibus lateraliter singulis punctis magnis. Pedes brunnei ; femora basi apiceque nigro-brunnea ; tibiae intermediae incisura magna, posticae areuatae.

Long. 23 mm., elytr. 16, lat. $6 \frac{1}{2}$.

Mandibles longitudinally striated, with the outer edge deeply longitudinally impressed; antennal tubers with a shallow broad groove immediately above the tooth near the tip. Sides of the prothorax with two faint transverse oblique grooves, - one basal, one apical-the grooves almost meeting each other above the coxal cavities. The tubercle on the base of the elytra steeper in front than behind, granular, with the tip rounded, smooth and shining; the punctures on the base of the elytra bearing a granule in front ; the conical tooth into which the apex of each elytron is prodnced clothed with rather strong hairs.

Hab. Kina Balu (Brit. N. Borneo).

\section{Zygocera niveosignata sp. nov.}

$Z$. nigra, dense sordide cinereo-brunneo-tomentosa, pilis brevibus griseis (elytris exceptis) tecta, antennis, tibiis tarsisque plus minusve cinereis, elytris singulis duabus signaturis niveis ornatis, una fasciiformi posthumerali ab margine externo oblique versus medinm suturae ascendente, suturam non attingente, in utroque latere multisinuata, parte dorsali parum retrorsum descendente, secunda subtriangulari anteapicali, ab margine externo oblique versus anticum usque ad medium disci ascendente, hic parum dilatata.

Caput longitudinaliter canaliculatum, fronte planatum, tuberibus antenniferis subcontiguis, oculornm lobis inferioribus obliquis. Antennae corporis longitudine, infra ciliatae, articulo tertio quarto vix, quinto fere duplo, longiore. Prothorax longitudine latitudini aequali, lateribus levissime rotundatus, tuberculo minuto postmediano armatus, fortiter coriaceo-rugatus, punctis grossis instructus, dorso ntrinque sat convexus et tuberculo mediano conspicuo notatus, linea mediana 
retrorsum parum depressa laevi. Scutellum longitudine duplo latins, fere semicirculare. Elytra usque ante apicem parallela, dein rotundata, angulis suturalibus leviter rotundatis, dorso dimidio basali subrecta, dein declivia, basi medio levissime elevata, irregulariter sat disperse punctulata, punctorum margine antico in basi fortiter granuliformi.

Infra punctis nigris dispersissimis notata. Abdominis segmentum ultimum medio profunde impressum. Femora postica segmentum quintum abdominale attigentia.

Long. $22 \mathrm{~mm}$., elytr. 15, lat. 8 .

Hab. Australia.(probably West Australia).

Accola gen. nor.

Ab Glenida Gahan differt: Labrum transversum, latitudine multo brevius; frons antice medio ( $\delta$ ) tuberculo armata, ( + ) levissime convexa, inter oculos leviter impressa ; oculorum lobus inferior minor ; prothorax inermis, retrorsum angustatus, postice fortiter constrictus ; elytra apicibus emarginato-truncata, angulis suturalibus subrectis, externis valde rotundatis.

In the outline of the front of the head, the form of the antennae, in the elytra being carinate at the sides, the intermediate tibiae entire, the claws simple and divaricate, the abdominal segment subequal in length, etc., this genus agrees with Glenida, from which it differs, on the other hand, in the above-given characters.

\section{Accola citrina sp. nov.}

(Pl. XIII., fig. 12.)

8\%. A. elytris obscure violaceis; antennarum articulis $5^{\circ}-11^{\circ}$, et $4^{\circ}$ apice, tibiis (basi excepta) tarsisque nigris, tibiis et tarsis nigro-hirsutis; caeteris partibus corporis rufis vel brunneis, dense citreo-flavo-pubescentibus.

Prothorax longitudine minime latior, antice levissime transverse sulcatus, disco ante basim medio levissime-elevato. Scutellum semicirculare. Elytra pone humeros parum angustata, punctis sat dispersis in basi magnis rotundis, mox pone medium minutissimis, piliferis instructa, pilorum longitudine retrorsum decrescente ; carina laterali in tertia parte apicali evanescente.

Metasternum fortiter convexum. Abdomen segmento ultimo canaliculato, apice truncato, medio levissime emarginato, angulis valde rotundatis.

Long. $16 \mathrm{~mm}$., elytr. 11, lat. $6 \frac{1}{4}$.

Hab. Shillong (Assam), July 1893.

A female in the Tring Museum, a male in the British Museum collection.

27. Glenea ochracea montana subsp. nov.

§. Major, elytris longioribus, retrorsum fortius attenuatis; prothorace vitta laterali nigro-brunnea notato, elytris margine externo nigro-brunneis.

Long. 13 mm., elytr. $9 \frac{1}{2}$, lat. 4 .

The colour of the derm of this form is darker than in G. ochracea (Guér.); the elytra are proportionally much longer and more narrowed behind, the metasternum is devoid of a lateral brown streak, and the longitudinal streaks of the abdomen are very faint.

Hab. Kina Baln (Brit. N. Borneo). 


\section{$2 \mathrm{BHL}$ Biodiversity Heritage Library}

Jordan, Karl. 1894. "On some new genera and species of Coleoptera in the Tring Museum." Novitates zoologicae : a journal of zoology in connection with the Tring Museum 1, 484-503. https://doi.org/10.5962/bhl.part.24569.

View This Item Online: https://www.biodiversitylibrary.org/item/24179

DOI: https://doi.org/10.5962/bhl.part.24569

Permalink: https://www.biodiversitylibrary.org/partpdf/24569

\section{Holding Institution}

Natural History Museum Library, London

\section{Sponsored by}

Natural History Museum Library, London

\section{Copyright \& Reuse}

Copyright Status: Public domain. The BHL considers that this work is no longer under copyright protection.

This document was created from content at the Biodiversity Heritage Library, the world's largest open access digital library for biodiversity literature and archives. Visit BHL at https://www.biodiversitylibrary.org. 